\title{
Eastern Europe, With and Without Borders
}

\author{
Wendy Bracewell
}

\begin{abstract}
A genealogy of the concept of 'Eastern Europe' and survey of the state of East European studies in Western academia lead to a discussion of the ways East European studies might absorb and build on recent critiques, contributing to a re-mapping of Area Studies more widely. As well as urging awareness of the geopolitical and academic forces that have defined Eastern Europe and East European studies in the past, the chapter underlines the heuristic potential and institutional advantages of multiple, overlapping and competing area concepts. Dialogues across different academic cultures (whether the differences are those of discipline, area, or geographical location) and a critique of the production and circulation of knowledge from a self-aware 'area' perspective feed into a larger project of critical Area Studies.
\end{abstract}

In the early years of the twenty-first century, the young Polish artist Jan Dziaczkowski (1983-2011) created a series of collages, inserting images of socialist-era architecture, monuments and everyday life into postcards of famous western European scenes. Grey tower blocks loom over Piccadilly Circus and march alongside the Leaning Tower of Pisa; a statue of Lenin dwarfs the building of Gropius's Dessau Bauhaus; Princess Diana glances up from work at an industrial loom; young women in headscarves, carrying rakes and brooms, stride purposefully through the Louvre or take notes, accompanied by a herd of cows, in front of a portico supported by caryatids. ${ }^{1}$

The series was entitled Keine Grenze or 'no border'. Its impact depends on the viewer recognizing the ways that these images do in fact encode the two sides of a border, that between Cold War Eastern Europe and the West: on the one side concrete monoliths, party leaders and women-as-workers, on the other side high culture, tourism, and bustling commerce. Precisely how the collages erase this division is open to interpretation. Is the artist in fact reinstating ideological and aesthetic borders by juxtaposing monochromatic socialist modernism with the canonical highpoints of western civilization? Or are these scenes from an imagined post-WWII past in which the Red Army did not halt at Berlin but continued as far as London, the fantasy of a twenty-first century in which all Europeans grapple equally with the legacy of communism? Perhaps they comment on the ways neither architectural styles nor political ideologies lend themselves to neat geographical divisions - after all, the concrete of the reallyexisting Centrepoint building just beyond Piccadilly rhymes convincingly with

${ }^{1}$ Jan Dziaczkowski - Kolaże, ed. K. Hordziej (Kraków: The Foundation for Visual Arts, 2013). 
the tower block glorifying the Communist Party of the Soviet Union that Dziaczkowski has inserted in the foreground. Or do these images summon up a contemporary, mobile world in which east European migrants now cross Europe's Cold War border to work or travel, but nonetheless carry their own historically-formed identities with them? In the context of the EU's 2004 eastward enlargement, the images (and their German title) inevitably read as an ironic comment on politicians' claims to have erased Europe's Cold War divisions.

These ambiguities of interpretation hint why Eastern Europe might be a fruitful starting point for reconsidering Area Studies. ${ }^{2}$ What is the genealogy of Eastern Europe as a concept and as an object of academic research? What is the position of East European Studies in the twenty-first century, and how might its assumptions be revised and its borders re-mapped? Can a project of Eastern Europe both with and without borders contribute to the reinvention of area studies more broadly?

Dziaczkowski's collages depend heavily on the signifiers of the Cold War, but the concept of a bounded and recognizable Eastern Europe is both older than the post-Second World War geopolitical order, and less clearly defined than the territories formerly ruled by Europe's communist regimes. The area so designated has been historically contingent, its borders and divisions fluid and frequently shifting, according to different, sometimes contradictory criteria. Eastern Europe is not equivalent to 'the eastern half of Europe' in geographical terms, not simply because the resulting anomalies (e.g. 'East European' Prague lying to the west of Vienna and Stockholm), but also in view of the frequent exemptions or qualifications made on non-geographical grounds (Cold War Greece being the most striking example). It is often more revealing to examine who is defining Eastern Europe or competing labels, where, and to what purpose, than it is to assess the validity of the criteria - historical, cultural, political or economic - used to delimit such areas.

The term Eastern Europe and its close cognates in other western European languages (Osteuropa, L'Europe orientale) only appeared in general use to designate a distinctive territory with shared characteristics in the early nineteenth century, though scattered references appear from the early eighteenth century, usually in the purely geographical sense of 'the eastern part

\footnotetext{
2 I use 'Eastern Europe' here as the term for the academic or geopolitical construct and mental map; 'eastern Europe' for an unmarked geographical space. 'East European Studies' designates the institutional framework for academic study of Eastern Europe (how Eastern Europe has been framed in a particular context determines whether this includes study of Russia or the Soviet Union).
} 
of Europe'. ${ }^{3}$ Through the eighteenth century, the more usual mental map of Europe was oriented North-South, with classical ethnography, climate theory, and religious-political competition shaping long-standing polemics over the qualities to be attributed to each side of this division. It was the Enlightenment in France that radically revised this imaginative geography of Europe, though not by re-orienting the map away from North-South through the invention of a single, coherent Eastern Europe, as so influentially argued by Larry Wolff. ${ }^{4}$ (Critics have pointed out that the eighteenth-century sources used by Wolff fail to use the term 'Eastern Europe' and retain the designation 'Northern' for Russia and Poland, often grouping these states with Sweden and Denmark, and that to project the Cold War division of Europe back into the eighteenth century, where the sources instead speak of individual peoples or places rather than clearly defined areas, is anachronistic.) ${ }^{5}$

The achievement of the French philosophes was instead to theorize Europe as a whole in terms of a teleological vision of history built around concepts of progress and civilization that privileged particular forms of technological and cultural change as developed in the great urban centres of north-western Europe. They defined 'Europeanness' through confrontation with a variety of others, including internal ones. It was not only eastern Europeans, but also 'backward' southern Italians or Irish, 'degenerate' Greeks, 'savage' Icelanders, 'uncivilized' Swiss or Breton villagers, or a 'barbaric' urban rabble who could serve as foils for the arbiters of an ideal Europeanness, though each specific notquite-European might occupy a different place in the march of history, from savagery to (potential) perfectibility to decadence. ${ }^{6}$ This effort to classify and rank degrees of Europeanness was further encouraged as early Enlightenment anthropology (or a universalist 'Science of Man') developed towards a much more particularist ethnology, or the science of the different varieties of mankind, increasingly conceived in hierarchical and determinist terms. Thus the intellectual origins of Europe's twentieth-century geocultural divisions can indeed be placed in the Enlightenment, as Wolff argues, but it is more helpful to see these eighteenth-century projections of self and other in terms of a self-

\footnotetext{
3 F.B. Schenk, 'Eastern Europe,' in European Regions and Boundaries: a Conceptual History, ed. Diana Mishkova and Balázs Trencsényi (New York: Berghahn Books 2017).

${ }^{4}$ Larry Wolff, Inventing Eastern Europe. The Map of Civilization on the Mind of the Enlightenment (Stanford: Stanford UP, 1994).

${ }^{5}$ See, e.g. M. Confino, 'Re-Inventing the Enlightenment: Western Images of Eastern Realities in the Eighteenth Century,' Canadian Slavonic Papers 36/3-4 (1994): 505-22.

${ }^{6}$ See, e.g., R.M. Dainotto, Europe (in theory) (Durham, N.C.: Duke University Press, 2007); B. Struck, Nicht West - nicht Ost. Frankreich und Polen in der Wahrnehmung deutscher Reisender zwischen 1750 und 1850 (Göttingen: Wallstein, 2006); H. Kliemann-Geisinger, 'Mapping the North: spatial dimensions and geographical concepts of northern Europe,' in K.K. Povlsen (ed), Northbound: travels, encounters, and constructions 1700-1830 (Aarhus: Aarhus UP, 2007).
} 
congratulatory scale of centre-periphery difference, rather than geographically divided East-West or North-South. (It is tempting to see contemporary scholars who focus solely on 'Eastern Europe', or 'the Southern Question', or 'the Orient' in explanations of the evolution of Europe's divisions and limits as suffering from that specific form of myopia caused by imagining areas as bounded, separate, and distinct.)

Eastern Europe as an explicit label for a coherent entity has a more recent genealogy, though with significant variations according to context. It emerged in German usage in the early nineteenth century as a response to the waning of the Ottoman threat and the rise of a Russian one. Liberal fears of an increasingly powerful reactionary, legitimist and interventionist Russian monarchy helped to shift Russia out of its former imagined place in the North (now left to Scandinavia) and placed it firmly in an 'Asiatic' and 'despotic' East. Osteuropa in German usage long retained an emphasis on Russia and its western borderlands. ${ }^{7}$ In French usage, in contrast, the idea of a distinctive European East spread in the mid-nineteenth century as a response to Panslav ideas: L'Europe orientale was the equivalent of 'Slavonic Europe' and helped widen the territory of Eastern Europe beyond Russia to the rest of the Slav world. Ezequiel Adamovsky has shown how this Eastern Europe was constructed as a 'space of absence', lacking various elements thought fundamental to 'Western civilization' -effective restraints on the power of the sovereign, urbanization and a bourgeoisie, and an independent civil society - whether these were conceived as positive or negative attributes. Adamovsky gives the resulting discourses of East European difference the label of 'Euro-Orientalism', underlining the way the binary stereotypes of Europe versus the Orient were adapted to new divisions of space, and showing how they served to organize and regulate relations of power. ${ }^{8}$ English usage of the term 'Eastern Europe' became entrenched still later: appearing as general currency shortly after the First World War (largely in response to the new postwar political order and building on Halford Mackinder's influential characterization of 'East Europe' lying at the centre of the 'geographical pivot' of world power), and becoming increasingly common during and after the Second World War. ${ }^{9}$

The powerful stereotypes and prejudices of Euro-Orientalism meant that the term 'Eastern Europe' - from the nineteenth century onwards - was used primarily to denote others, only seldom as self-description. When it was used in

\footnotetext{
${ }^{7}$ H. Lemberg, 'Zur Entstehung des Osteuropabegriffe im 19. Jahrhundert. Vom 'Norden' zum 'Osten' Europas', Jahrbücher fur Geschichte Ost-Europas 33 (1985): 48-81.

8 E. Adamovsky, Euro-Orientalism. Liberal Ideology and the Image of Russia in France (Oxford: Peter Lang, 2006).

${ }^{9}$ Halford Mackinder, 'The Geographical Pivot of History,' Geographical Journal 23 (1904): 421-37.
} 
the eastern half of continent, it was generally employed to differentiate the observer's position from those societies and cultures perceived as more 'eastern', in a self-defensive process that has been described as 'nesting orientalism'. ${ }^{10}$ Similar processes were reproduced within European societies, as with 'class orientalism' directed towards social inferiors, 'internal orientalism' aimed at domestic peripheries, or as 'self-orientalism', manifested as an internalized sense of backwardness and shame. However, such east European 'ideologies of Eastness' have not necessarily translated into the acceptance of an explicitly 'East European' selfhood. ${ }^{11}$ More frequent assertions of a distinctive Central European self have also been shaped by self-defensive urges, with the difference that such definitions can be understood as establishing a distance visà-vis both East and West, on the one hand resisting the pejorative connotations of Easternness, on the other defying relegation to a mere periphery of a more advanced West. ${ }^{12}$ 'The Balkans', like Eastern Europe, was also initially defined from without as an ambiguous demi-Europe, as analyzed by Maria Todorova. ${ }^{13}$ However, while these external definitions may have emphasized the degree of Balkan difference from a truly European core, local adaptations of the Balkan concept have also called attention to patterns of connection, interaction and convergence (the very opposite of western definitions of Balkanization as fragmentation, as Diana Mishkova has pointed out). ${ }^{14}$

After the First World War the establishment of the independent successor states reinforced a tripartite division of Europe into West, East and something in between. However, there was no consensus as to what this 'something' was. The appropriate terminology was hotly debated, particularly within the region: should it be understood in terms of Mitteleuropa, Zwischeneuropa, Slavic Europe, Central Europe (sometimes itself divided into West-Central and East-Central Europe), 'New' Europe, or an Eastern Europe marking the boundary with an implicitly non-European Russia? Different interests and visions of the future underpinned the choice of terminology: was it a 'shatter zone', a buffer and

\footnotetext{
10 Milica Bakić-Hayden, 'Nesting Orientalisms: the case of former Yugoslavia,' Slavic Review 54/4 (1995): 917-931; W. Bracewell, 'The limits of Europe in east European travel writing,' in W. Bracewell and A. Drace-Francis (eds), Under Eastern Eyes: a Comparative Introduction to East European Travel Writing on Europe (Budapest: CEU Press, 2008).

11 T. Zarycki, Ideologies of Eastness in Central and Eastern Europe (New York: Routledge, 2014).

12 P. Bugge, 'The use of the middle: Mitteleuropa vs. Střední Evropa,' European Review of History-Revue européenne d'Histoire 6/1 (1999): 15-35.

13 Maria Todorova, Imagining the Balkans (Oxford: Oxford UP, 1997).

14 Diana Mishkova, 'Academic Balkanisms: Scholarly Discourses of the Balkans and Southeastern Europe' in Entangled histories of the Balkans, 4 ('Concepts, Approaches, and (Self-)Representations'), ed. R. Daskalov, Diana Mishkova, Tchavdar Marinkov, and Alexander Vezenkov (Brill: Leiden, 2017): 44-114.
} 
bridge, or a sphere of German or Russian influence? Where did the boundaries lie, and were the criteria contemporary, political, and contingent, or cultural, historical and 'natural'? And if the latter, which of the numerous cross-cutting indicators overrode the others? The answers to these questions depended on who was making the argument, and to what ends. ${ }^{15}$

These multiple differentiations were temporarily resolved by a new polarization of Europe after the Second World War (one which also elevated the East/West division over other European fractures). The concept of a cohesive Eastern Europe, now including the Soviet Union, became entrenched in the capitalist West as a synonym for the European socialist republics, though the primarily ideological basis for the collective label was tinged with older Euro-Orientalist prejudices. The postwar shift in the imagined location of Greece, from the East to the West, underlines the primacy of ideology, however: geopolitics outweighed the cultural, economic and political factors that otherwise might have placed Greece in Eastern Europe. On the other hand, while representatives of the socialist states often spoke in geopolitical terms of 'the West' as the enemy of communism, they rarely identified themselves as 'Eastern Europe'. A different self-descriptive terminology of the socialist 'camp' or bloc implied ideological choice and not cultural or geographical destiny. And at least at first, this selfdesignation also laid claim to a revolutionary shift in the location of progress and modernity, even if this was eventually followed by retreat and retrenchment in the face of Soviet military intervention, Cold War competition over consumption as well as production, and political sclerosis. (This in turn fed the disillusioned and backward-looking revival of 'Central Europe' in opposition to a variously defined East - and an indifferent West - in certain parts of the region in the 1980s.) $)^{16}$

After 1989-91 and the collapse of the socialist regimes, many in both East and West predicted the end of a distinctive Eastern Europe, perhaps best summed up by the opening line of a 1990 article by Hungarian-born Charles Gati in Foreign Affairs, subtitled 'The Morning After': 'Eastern Europe is now east-central Europe'. ${ }^{17}$ But the earlier label hung on, though less often with a Russian component: the EU accession states were often complimented with the term 'the former Eastern Europe', as if they had somehow shifted their geographical location as well as changed their political and economic framework. However,

\footnotetext{
15 See Diana Mishkova and Balázs Trencsényi (eds), European Regions and Boundaries: $a$ Conceptual History (New York: Berghahn Books 2017), especially the chapters by B. Trencsényi ('Central Europe'), F.B. Schenck ('Eastern Europe') and S. Troebst ('European History').

16 George Schöpflin and Nancy Wood (eds), In Search of Central Europe (Cambridge: Polity Press, 1989).

17 'East-Central Europe: The Morning After,' Foreign Affairs 69/ 5 (1990/91): 129-145.
} 
when citizens of these countries exercised their right to travel and work across Europe, disapproving observers lumped them together and stigmatized them as 'East European', using the same label for corruption, xenophobia, aggressive nationalism or populism when these occurred in accession states (though these same phenomena were rarely 'un-European' when observed in Western member nations). 'Post-socialism' or 'post-communism' offered a more neutral label, for both insiders and outsiders, as a term indicating the shared experience of state socialism and subsequent radical transformation processes. However an analytical category built on shared legacies could also be applied as an implicit geographical designation, grouping together countries in the east of Europe while usually excluding such states as Mongolia, Vietnam or China. The competing solutions, in journalism, diplomacy and academic usage, indicated that the criteria could be sliced and diced in different ways.

This brief sketch of Eastern Europe and its variants highlights the contested nature of these area labels, projected, disputed, claimed or rejected, sub-divided and re-negotiated. The arguments have nearly always been underpinned by the logic of alterity rather than arising from observable commonalities, though shared economic, political or social factors, historical patterns, or cultural traits have all been pressed into service in the process. The salient categories of difference have changed with new anxieties or alliances, contributing to the unstable and contingent - though scarcely arbitrary - nature of the definitions. These have developed within an over-arching East/West framework, although those nations and places designated as East European have not necessarily accepted the denomination. Nonetheless, insider voices have also contributed to the East-West orientation of Europe, whether through their own local 'ideologies of Eastness' or by changing the terms while retaining the basic equation ('the socialist camp'). However, the underlying binary division could also produce much more complex configurations, as the arguments over Central Europe or an East-West political, economic or cultural 'gradient' indicate. ${ }^{18}$

But the salient point here is not the criteria or even the purposes of such definitions, revealing as they may be. It is that there was never a consensus. What 'area' meant could not be taken for granted as solid and self-evident in this part of Europe: it was always up for debate and challenge. And in consequence, even while they passionately argued for their own definitions, proponents of these debates were also pushed to produce some notable reflections on the

\footnotetext{
18 See, e.g., Daniel Chirot (ed), The Origins of Backwardness in Eastern Europe: Economics and Politics from the Middle Ages until the Early Twentieth Century (Berkeley, California: University of California Press, 1989); Catherine Evtuhov and St Kotkin (eds), The Cultural Gradient: The Transmission of Ideas in Europe, 1789-1991 (Rowman \& Littlefield, 2003); A. Melegh, On the East-West Slope: Globalization, Nationalism, Racism and Discourses on Central and Eastern Europe (Budapest: Central European University Press, 2006).
} 
criteria, purposes, and implications of area concepts, whether in interwar debates about the limits and divisions of European history, or meditations in the 1980s on supra-national cultural collectivities, or deconstructions of the symbolic geographies of the region in the 1990s. From this perspective, Dziaczkowski's 'without borders' collages represent a provocation to the viewer, calling for reflection not just on the contradictions of EU integration but also on the ambiguities of Europe's East/West divisions. While unstable and fluid frontiers are by no means unique to Europe's eastern edge, its competing and interacting discourses of inclusion and exclusion, connection and difference, make this a fruitful site for thinking through the purposes and possibilities of area concepts.

East European Area Studies - as institutionalized in university departments, research institutes and specialist journals - has been subjected to a now wellestablished critique, reflecting a wider reassessment of Area Studies in general. The narrative has focused on the conscription of western East European Studies to Cold War and post-1989 geopolitics and the ways in which the resulting knowledge has been compromised and rendered suspect. According to this critique, East European Studies was the product of the same geopolitical gaze that produced Eastern Europe in the first place, being predicated on a political and intellectual distance between Western experts and the objects of their knowledge. State interests demanded that this knowledge be useful and problem-solving (predictive or, after 1989-91, prescriptive). Area Studies critics have seen state-controlled funding as the mechanism by which academic energies were harnessed to this purpose, with the ebb and flow of Euro-Atlantic strategic interest determining the establishment and fortunes of institutions devoted to East European Studies. Precisely how individual scholars were conscripted into this is usually less clearly articulated, though the implication is that it came down to ideological alignment, institutional coercion, or individual conformism. Area and discipline are conceived as separate and opposing intellectual fields in this portrayal, with East Europeanists depicted as isolated from mainstream disciplinary methods, theories and problems, though the integration of multiple disciplinary approaches to the object of study is conceded a pragmatic 'holism' - though at the expense of oversimplifying a problematically undifferentiated Eastern Europe. Though versions of this narrative have circulated since at least the 1960s, the main stimulus for recent iterations was the sudden and radical collapse of the Cold War division of Europe after 1989-91. This laid bare the limits of East European Studies' capacity to predict change and highlighted the pragmatic motives behind state funding, particularly as investment rapidly shifted to other areas of concern. Even as multidisciplinary East European Studies was reinvented in response to new crises, attracting new 
participants from other fields, and under other labels - transitology, conflict (and post-conflict) studies, or EU integration studies - the same criticisms continued, of a 'colonial paradigm' subservient to hegemonic state interests from one direction, and of a lack of disciplinary rigor from the other. ${ }^{19}$

Admittedly the foregoing summary is something of a caricature, but the criticisms leveled at East European Studies often themselves caricature the practices held up to analysis. It is conventional to respond that things are much more complicated than that, ${ }^{20}$ but in what follows the point is what the airbrushed complexities reveal about the character of East European Studies, broadly understood, and about the processes by which knowledge is produced. Looking at the details reveals not unthinking conscription to geopolitical power but rather the entangled character of East European Studies, and the intellectual consequences of its unorthodox (though not undisciplined) constitution.

The extent to which western scholars of Eastern Europe have spoken for power is a matter of time, place and degree. The paradigmatic model for academic subservience to political demands is not Cold War East European Studies or even US Sovietology, but Nazi-era Ostforschung, conscripted to the subjection and exploitation of the territories and people's to Germany's east, with the instrumentalization of academic research ensured both by targeted funding and by the willingness of the Ostforscher to 'work towards the Führer' in anticipating the commands of the state. ${ }^{21}$ Elsewhere, state direction of western East European Studies has rarely been so all-encompassing, even if those in charge might have wished it so. This has been the case even under the highly centralized state funding regime of UK Higher Education, where the School of Slavonic and East European Studies provides a good illustration of the academic power/knowledge relationship. Established in 1915 with the explicit intention of influencing Britain's war aims and postwar policy towards the 'small nations' of Eastern Europe (and with direct financial support from their heads of state), its founders' hopes that SSEES would shape British diplomacy were curtailed by official suspicion of the researchers' bias (not least because most of the first

${ }^{19}$ See, e.g., Ian Klinke, 'Area studies, geography and the study of Europe's East,' The Geographical Journal 181/4 (2105): 423-26; Gareth Dale, Katalin Miklossy, Dieter Segert (eds), The Politics of East European Area Studies (London: Routledge, 2016).

${ }^{20}$ A good study on these lines is D. Engerman, 2009 Know your enemy: the rise and fall of America's Soviet experts (Oxford: Oxford University Press, 2009), as well as the essays in David Szanton (ed), The Politics of Knowledge: Area Studies and the Disciplines (Berkeley, CA: University of California Press, 2004).

${ }^{21}$ Michael Burleigh, Germany Turns Eastwards: a Study of Ostforschung in the Third Reich (Cambridge: Cambridge University Press, 1988); Ingo Haar 'German Ostforschung and anti-semitism' in German scholars and ethnic cleansing 1919-45, ed. Ingo Haar and Michael Fahlbusch (New York: Berghahn Books, 2004); see also Ian Kershaw, 'Working Towards the Führer": Reflections on the Nature of the Hitler Dictatorship', Contemporary European History 2/2 (1993): 103-118. 
generation of scholars were recruited from the region). After the Second World War, in very different circumstances, not least the decision to rely on more conventional state educational funding, successive academic managers were happy to 'work towards the Foreign Office', not just in mission statements responding to UK strategic needs but on occasion through personnel decisions. Most controversially, in 1950 this meant not renewing the contract of a founder member of the British Communist Party hired to lecture on Soviet institutions, over public protests about academic freedom from members of staff and students. ${ }^{22}$ But as this suggests, top-down managerial and bottom-up academic views did not always completely coincide. Nor have strategic funding initiatives invariably had the intended results: subsidies for language training, for instance, may have been intended to nurture expertise for diplomatic or military needs, but what students actually did with their skills could vary widely (at least two Soviet spies, Kim Philby and Geoffrey Prime, had been students on University of London Russian courses). And of course academics have long been adept at responding to the language of funding calls to further their own research interests. Partly because of doubts about academic trustworthiness, the Foreign Office has generally preferred to rely on its own research departments to underpin policy making about the region. The same could be said about US government agencies, which as early as the late 1950s were relying on their own in-house experts, increasingly under the aegis of what David Engerman has labeled 'para-academic enterprises' existing at a distance from academic debates and scholarly norms (e.g. RAND, Washington think-tanks, or university-based policy institutes such as the Hoover Institution at Stanford). However, the degree to which even this in-house knowledge achieved policy traction was also in practice subject to political manipulation and government infighting. ${ }^{23}$

The same lack of congruence between official prescript and academic practice can also be seen elsewhere. Even during the height of anti-communist McCarthyism the field accommodated a spectrum of political perspectives something already apparent in the OSS Research and Analysis Branch, the wartime precursor to the institutionalization of Area Studies. ${ }^{24}$ Some scholars, particularly in policy-oriented subjects, have benefitted from a revolving door between the academy and government, though the career of someone like

\footnotetext{
22 Ian Roberts, History of the School of Slavonic and East European Studies, 1915-1990

(London: University of London, School of Slavonic and East European Studies, 1991), 43, 48; Maurice Pearton, 'The History of SSEES: The Political Dimension', The Slavonic and East European Review 71/ 2 (Apr., 1993): 287-294.

${ }^{23}$ Engerman, op. cit., 261-85. Memoirs touching on the politics of official intelligence manipulation are often revealing in this respect: see, e.g., Melvin Goodman, Whistleblower at the Central Intelligence Agency (San Francisco: City Lights Publishers, 2017).

24 Barry M. Katz, Foreign Intelligence: Research and Analysis in the Office of Strategic Services, 1942-1945 (Harvard, Mass.: Harvard University Press, 1989).
} 
Zbigniew Brzezinski (Polish-born national security advisor to Jimmy Carter, and an opponent of Cyrus Vance's pursuit of détente, arguing for direct engagement with Eastern Europe as a means of countering Soviet power) highlights the sharp divisions in approach that could exist within government, as well as in the academic world. Equally, both US and European academics, inside and outside the circles of power, could and did voice criticism of official policy towards the region as misconceived, blinkered, and ultimately counter-productive. (The critique of the university-state nexus tends to ignore these more critical perspectives, though they certainly aspired to change if not set official policy.) In general, the degree to which academic production directly served state interests could vary widely and was not always predictable. ${ }^{25}$ Overall, geopolitics and state funding worked to create structures within which a wide range of disciplines - including literature and philology - could work to produce knowledge about Eastern Europe, not all of it with an immediately practical application.

These structures also accommodated a cosmopolitan mix of scholars. There was never a clear-cut division between Western 'experts' and their objects of study in eastern Europe. SSEES was scarcely alone in recruiting specialists from the region. This was a necessity for the rapid development of post-WWII area expertise in the United States, which had little pre-war tradition of scholarship focused on Eastern Europe. ${ }^{26}$ And scholars from the region had a great, even a decisive influence in many aspects of western East European Studies. This included some of its ideological leanings - Cold War anti-communism in western East European Studies was certainly reinforced by successive waves of émigré scholars (and, on a slightly different tack, one might also point to the large role played in western Soviet studies by émigrés from Russia's borderlands, with their own specific perspectives). ${ }^{27}$ Anti-communism was by no means the rule, however, and reform-minded émigrés were also an important part of the story, particularly after 1956 in Hungary and 1968 in Czechoslovakia. Western scholars had their own entanglements with their regions of study, often going beyond scholarly interest. Richard Clogg, in his memoir of academic life in UK area studies in the 1970s-80s, recalls totting up a list of staff at SSEES who were married to aliens: 'a disproportionately high number, beginning at the top'. ${ }^{28}$

\footnotetext{
25 See, e.g., David C Engerman, 'Social Science in the Cold War', Isis, 2010, 101:393-400, and for more recent examples, Keith Brown (ed), Transacting Transition: The Micropolitics of Democracy Assistance in the Former Yugoslavia (Bloomfield, CT: Kumarian Press, 2006).

${ }^{26}$ See, e.g., Maria Zadencka, Andrejs Plakans, and Andreas Lawaty (eds), East and Central European History Writing in Exile 1939-1989 (Leiden: Brill, 2015).

${ }^{27}$ For instance the Polish-born US Sovietologists Richard Pipes, Roman Szporluk, Seweryn Bialer and Zbigniew Brzezinski.

${ }^{28}$ Richard Clogg, Greek to Me: A Memoir of Academic Life (London: I.B. Tauris, 2018), 120.
} 
This was also more widely true (and may well have contributed to official suspicion of the ideological bona fides of area scholarship).

However, a more important consequence of such cross-cultural flows for our understanding of the way area knowledge was produced was the fact that academics travelling east to west had a direct influence on the ways that East European Studies were pursued outside the region. One way in which this happened was that they carried with them their own scholarly traditions. These included highly developed disciplinary schools - Polish sociology, Hungarian approaches to economics and economic history, or Russian formalism and the Prague linguistic school. Émigré scholars (as well as those publishing in translation in the West) also contributed importantly to the critical use of Marxist theory in analysing economic and political change. But their perspectives could also operate at a micro level, for instance importing locally-inflected concepts of the frame and the scale appropriate for specific questions. This was not necessarily limited to an insistence on the national framework, though 'nationalist' was an easy label with which to disparage émigré scholarship. In addressing issues that went beyond contemporary Warsaw Pact relationships, it is striking how productively many such scholars resisted the undifferentiated concept of 'the Soviet Bloc' characteristic of some official Cold War perspectives, looking instead to other units of analysis: culturally determined regions, imperial legacies, or developmental patterns. Such approaches then had a profound influence on subsequent western scholarship. An example is that of Oscar Halecki's Limits and Divisions of Europe (New York-London, 1950) which emerged from interwar Polish-Czech-German debates over the character and role of central Europe, but was influential in western historiography for its challenge to a simple East-West division of European history (and to a certain extent, the exclusion of Russia from that history). ${ }^{29}$

A different example of moving beyond the focus on the national hinges on the personal experience of émigré dislocation and the cosmopolitan ability to operate in multiple linguistic environments. For successive waves of scholars from eastern Europe (Georg Lukács, Roman Jacobson, René Wellek; or Tzevtan Todorov and Julia Kristeva), this 'productive insecurity' contributed to the development of modern literary theory, shaped by the effort to look beyond the national characteristics of literature - rendered irrelevant by their circumstances - and formulate abstract laws to grasp its workings. ${ }^{30} \mathrm{~A}$ further layer of complexity could be added by following the strategic and scholarly

\footnotetext{
${ }^{29}$ On Halecki and his influence, see Stefan Troebst, 'Meso-Regionalizing Europe: History versus Politics', in Domains and Divisions of European History, ed. by Jóhann Páll Árnason and Natalie Doyle (Liverpool: Liverpool UP, 2010).

${ }^{30}$ Galin Tihanov, 'Why did modern literary theory originate in Central and Eastern Europe? (And why is it now dead?)' Common Knowledge 10/1 (2004): 61-81.
} 
appropriation, adaptation and rejection of concepts and approaches from west to east, or indeed in other directions. These might include important though uneven counter-flows of theoretical influences before 1989 (translations of, for instance, Levi-Strauss into Polish before 1970; Herbert Marcuse or Franz Fanon into Serbo-Croat in the 1960s and 1970s; Immanuel Wallerstein into Hungarian in the 1970s); strategic use of Western concepts and paradigms by indigenous or returnee scholars after 1989-91 for purposes of prestige or self-legitimation; and subsequent debates over hierarchies of knowledge and the relative value accorded to 'western theory' and 'local knowledge'. ${ }^{31}$ In short, it is impossible to isolate western and east European contributions to knowledge about the region: both in terms of personnel and research perspectives, the two are inextricably entangled.

And, finally, the polarization between 'area' and 'discipline' in East European Studies has rarely been so absolute or so consistent as is claimed. Rather than being firmly defined by the logic of either/or, forcing scholars to choose between adherence to the conventions of a discipline or immersion in the particularities of a place and culture to the exclusion of wider theoretical concerns, East European Studies has primarily been characterized by both/and. Whether located in the humanities or the social sciences, academics working on east European subjects have necessarily tested the methods, presuppositions, and assumptions of their disciplines against the sometimes intractable peculiarities of local and specific contexts in relation to a wider world. And they have made contributions, in turn, to problems and approaches in the disciplines, whether measuring economic growth in non-capitalist economies, comparing the trajectories of modernizing societies, examining conflicts and cleavages in a nondemocratic system, or querying grand narratives from positions outside the mainstream. Debates around the poverty of disciplinary theory on the one hand, or the parochialism of an area focus on the other are, paradoxically, testimony to a close area-discipline enmeshment in East European Studies: for the most part they have arisen within the field, and often signal other tensions - between academic and policy relevance, for instance, among political scientists concerned with the region in the 1960s and 1970s, or the asymmetrical relations between postcolonial and postsocialist studies. ${ }^{32}$

\footnotetext{
${ }^{31}$ Anthropology between western and eastern scholarship provides a good example for this last point; see, inter alia, the debates in P. Skalnik (ed), Struggles for Sociocultural Anthropology in Central and Eastern Europe (Prague, 2002); M. Buchowski 'Intricate relations between Western anthropologists and Eastern ethnologists,' Focaal - European Journal of Anthropology 63 (2012): 20-38; Hana Červinková, Michał Buchowski, and Zdenek Uherek (eds), Rethinking Ethnography in Central Europe (London: Palgrave Macmillan, 2015).

32 On political science and policy relevance in Sovietology, Engerman op. cit, 255; on postcolonial/postsocialist relations, S. Chari and Katherine Verdery, 'Thinking between
} 
Cross-disciplinary fertilization and collaboration are often lauded as the greatest theoretical and methodological advantages of area studies. Yet interdisciplinarity is not necessarily inherent in area studies. In East European Studies, the way it has been practised has been historically contingent, and often asymmetrical in the disciplines involved rather than holistic. Thus, for instance nineteenth- and twentieth-century scholars engaged in nation-building across eastern Europe were the pioneers of interdisciplinary area studies approaches, drawing simultaneously on philology, ethnography, history and geography in a single project of (self-)knowledge. Elsewhere, the combinations could be quite different. In the UK Bernard Pares introduced interdisciplinary 'Slavonic Studies' at Liverpool University in 1907, inspired by a similar approach in Berlin and focusing on language and literature as the primary means of understanding the wider culture. This focus also underpinned the approach at SSEES, under Pares' influence: the core disciplines remained philology, literature and history (with a joint post with the LSE in economics). It was only in the 1960s that new posts in the social sciences were finally added (many of them also held jointly with other institutions and only loosely integrated into the research context). ${ }^{33}$ In the United States, the emphasis was instead on the social sciences from the beginning in the OSS's Research and Analysis Branch, which brought together academics from history, economics, political science and geography: the socalled 'chairborne division' of the war effort. ${ }^{34}$ Postwar area studies of the region continued this emphasis, with the humanities disciplines far less closely entwined in US Cold War East European Studies (language teaching for pragmatic purposes was another matter).

But precisely how these disciplines have interacted has also been contingent. Holistic interdisciplinary projects have largely been promoted by external pressures and incentives. Large-scale projects and funding faded after the immediate wartime and postwar problem-oriented impetus; since the early 1990s they have revived with EU-funded projects focused on European integration and stability. However, East European Studies' methodological and theoretical interdisciplinarity has more typically been spontaneous, traced by what Marjorie Garber, the Harvard cultural critic, has called 'desire lines', borrowing an urban planning term for unauthorized pedestrian-created paths to characterize the traffic between established disciplines. ${ }^{35}$ The heaviest traffic in East European Studies has probably run between the different social sciences, but has also drawn in aspects of the humanities. Modernization theory, for

the Posts: Postcolonialism, Postsocialism, and Ethnography after the Cold War,' Comparative Studies in Society and History 51/1 (2009): 6-34.

${ }^{33}$ Roberts, op. cit., 54.

${ }^{34}$ Katz, op. cit., xii.

35 M. Garber, Academic Instincts (Princeton: Princeton UP, 2001), 53-54. 
instance, originally developed in sociology, became a widely shared paradigm for East European Studies scholars pursuing problems dealing with economic change, the development of political institutions, or the influence of literacy on cultural production. As the term 'paradigm' suggests, some such initially spontaneous connections have been cemented in place, becoming so normalized as to have lost their interdisciplinary connotations, and then challenged not because they troubled disciplinary norms but because of criticism from many different directions, theoretical as well as empirical.

This process of cross-disciplinary path-beating has not been peculiar to East European Studies. Fields such as gender, nationalism, Holocaust studies or borderland studies have been criss-crossed by interdisciplinary desire lines that now scarcely raise an eyebrow. In spite of claims that interdisciplinarity as a method defines area studies in general, for East European Studies at least it would be more accurate to say that it is multi-disciplinarity that has given the field its special character. To the extent that academics have worked within the institutional structures of East European Studies, whether in programmes, departments, journals or conferences, they have also rubbed up against the ideas, assumptions and approaches of colleagues working from different disciplinary perspectives on the same part of the world. (The same at least in theory. In practice, the differences between Balkanists and Russianists, say, can be at least as great as those between distinct disciplines.) Importantly, this close contact has been social as well as scholarly, promoting the sort of informal exchange that encourages cross-disciplinary intellectual communication. The advantage of multi-disciplinary area studies is that it maximizes the potential for interdisciplinary serendipity by stoking the desire and shortening the lines connecting the disciplines. But the primary impetus remains the problem itself. Interdisciplinarity is not simply an abstract exercise or rule breaking for its own sake.

In conclusion, this brief sketch attempts to show the complex ways in which area, discipline, interdisciplinary connections, politics, legacies, and the circulation of people and ideas have entwined and interacted in the field of East European Studies. The knowledge that has emerged from these encounters has been multifaceted: not solely contextual and particular but simultaneously contributing to wider projects of knowledge (not least challenging universalist aspirations). Still, although it is difficult to see this project as constituted along clear-cut borders - between them and us, area and discipline, humanities and social sciences, left and right, East and West - East European Studies has been haunted by such divisions and has returned to them repeatedly, not least in debates about the character and value of area-based knowledge. In this sense, Jan Dziaczkowski's collages, simultaneously eliding the borders between East and West while at the same time drawing the viewer's attention to them, stand 
as a nicely ironic metaphor - not so much for East European Studies as for this outline of its genealogy and recent history. But many of the possible versions of 'borderlessness' that can be read into those same collages - entangled histories, shared legacies, mobile cultures - are also transferable to the Area Studies project. East European Studies cannot easily be bracketed off from other fields of study, whether in disciplinary terms or in relation to Europe and the wider world.

The events of 1989-91, the Yugoslav wars of the 1990s, and EU eastwards expansion in the 2000s all contributed to a prolonged sense of crisis in western East European Studies. 'Eastern Europe' no longer appeared as a single, separate unit (if it ever had done), and both the purpose and the coherence of East European Studies were put in doubt. If 1989 marked a 'return to Europe', as the slogans had it, why should scholars insist on a backward-looking East European distinctiveness? What tied a EU-bound east-central Europe to the fractious Balkans? These questions were reflected in institutional form, in changes in the names of journals and professional associations and in departmental mergers, accelerated in some cases by shifting official funding regimes that de-emphasized eastern Europe in favour of other priorities. ${ }^{36}$

The same sense of crisis underpinned a lively debate over the very idea of a bounded, 'natural' Eastern Europe and its sub-units or alternatives. Beginning in the 1990s, a whole series of influential studies drew on the model of Edward Said's Orientalism to analyze the ways western actors (travellers, journalists and diplomats, as well as academics) had 'invented' or 'imagined' Eastern Europe, the Balkans, or Russia as useful 'others', laying bare the self-interested motives that animated these projections. ${ }^{37}$ These discussions had serious implications for the conceptualization and practice of East European Studies. It was not just that geopolitical interests tainted the field by association, or that its referent evaporated under deconstruction. If Eastern Europe or the Balkans were simply epiphenomena, brought into being as a reflection of Western interests and anxieties, then there was no reason to pay attention to anything outside or beyond the all-powerful West. Though phrased as a critique of western scholarship and a sympathetic defense of its objects, in practice this

\footnotetext{
${ }^{36}$ See especially Ellen Comisso and Brad Gutierrez, 'Eastern Europe or Central Europe? Exploring a Distinct Regional Identity' in Szanton (ed), op. cit., 262-312, for a survey of the issues as they appeared in the early 2000s.

${ }^{37}$ Among the most influential were Wolff, op. cit.; Todorova, op. cit.; also Iver Neumann, Uses of the other: 'the East' in European identity formation (Manchester: Manchester University Press, 1999) and others.
} 
deconstructive trend had the effect of marginalizing the study of eastern Europe. ${ }^{38}$

This approach soon came under criticism from two directions. The first queried the rather one-sided assumptions about the primacy of external, western agency in the construction of Europe's imaginative geographies. (This could scarcely be labeled Eurocentrism, but the thrust was the same; 'West-centrism'?) This prompted a productive line of research into east European contributions to the production of Europe's mental maps and the uses to which these actors put such concepts. ${ }^{39}$ The other direction of critique centered on structural criteria for defining historical regions, particularly in terms of political, historical and cultural frameworks or clusters of characteristics. Here there were many different and often conflicting arguments, advancing particular traits or boundaries as determinative, from Huntington's clashing 'civilizations' to Bideleux and Jeffries' semi-peripheries, to choose only two post-1989 framings of Eastern Europe. ${ }^{40}$ The tendency in these debates was to reaffirm the objective existence of the area (however defined) prior to subjecting it to analysis. The many possible overlapping and contradictory possibilities, however, continued to destabilize essentialist or 'scientific' approaches to defining the region. ${ }^{41}$

At the same time, various research topics across the disciplines were causing renewed reflection on Eastern Europe and related area configurations as categories of analysis. The diversity of outcomes in the processes of postcommunist transition, as well as continuing differences between post-communist and non-communist societies, led political scientists, in particular, to examine the effects of historical legacies - but the legacies of which histories? This problem required analysts to consider different eras (pre-communist, communist era, post-communist), institutional structures (empires, nation-states, and the Soviet Bloc, but also ecclesiastical frameworks or legal systems), and social and economic patterns. No single area definition could encompass all these crosscutting and over-lapping histories. As Grigore Pop-Eleches has pointed out,

\footnotetext{
38 See, e.g., W. Bracewell and Alex Drace-Francis, 'Southeastern Europe: history, concepts, boundaries,' Balkanologie 3/2 (1999): 47-66.

${ }^{39}$ E.g., on east European images of Europe, W. Bracewell and A. Drace-Francis (eds), Under Eastern Eyes: a Comparative Introduction to East European Travel Writing on Europe (Budapest: CEU Press, 2009); or of the West, György Peteri (ed), Imagining the West in Eastern Europe and the Soviet Union (Pittsburgh, PA: University of Pittsburgh Press, 2010). This line of research has heavily influenced arguments for an entangled history of ideas of East and West in Europe.

${ }^{40} \mathrm{~S}$. Huntington, The Clash of Civilizations and the Remaking of World Order (New York: Simon \& Schuster, 1996); R. Bideleux and I. Jeffries, A History of Eastern Europe (London: Routledge, 1998, $2^{\text {nd }}$ ed. 2008).

${ }^{41}$ Mishkova \& Trencsényi (eds), op. cit., is an invaluable survey of the history and use of regional concepts in Europe that makes this point by default.
} 
Eastern Europe as a category might work as a framework for analyzing the specific legacies of communist rule, but it is much less appropriate for a longerterm perspective, both because it arbitrarily bisects Europe's more gradual EastWest and North-South economic and cultural gradients, and because of the radically different historical experiences of the countries grouped together within that category.42 This discussion reflected a debate over scale and the selection of cases that emerged in other comparative projects as well. Arguments over inter-regional generalization versus regional specificity in understanding democratization processes prompted one notable polemic over these issues with reference to East European Studies, ${ }^{43}$ but similar issues of framing and the most appropriate units of analysis cropped up in many other fields of comparative research encompassing the region, from memory studies to the history of mass violence and genocide. ${ }^{44}$ In these debates, Eastern Europe emerged as just one possible framework, not necessarily constructed on an arbitrary basis, but primarily useful for its heuristic potential.

While the spatial turn and comparative research tended to deconstruct Eastern Europe (or at least to draw attention to its constructed nature), a new interest in transnational entanglements and cultural transfers turned attention to Eastern Europe and its variants as meso-regions, units existing above and beyond the level of the nation-state, but from this perspective constituted through connections and relationships rather than shared characteristics. Thus, for

42 Grigore Pop-Eleches, "Pre-communist and Communist Developmental Legacies", East European Politics and Societies (Special Issue: Whither Eastern Europe? Changing Approaches and Perspectives on the Region in Political Science), 29/2 (May 2015): 391408; see also M. Beissinger \& S. Kotkin (eds), Historical Legacies of Communism in Russia and Eastern Europe (Cambridge: Cambridge UP, 2014).

${ }^{43}$ See Valerie Bunce, 'Should Transitologists Be Grounded?' Slavic Review 51/1 (1995): 111-127; Terry Lyn Karl and Philippe Schmitter, 'From an Iron Curtain to a Paper Curtain: Grounding Transitologists or Students of Postcommunism?', Slavic Review 54/4 (1995): 965-978; and Valerie Bunce, 'Paper Curtains and Paper Tigers', Slavic Review 54/4 (1995): 979-987 for the key exchanges.

44 The conference of the Genealogies of Memory project, 'Regions of Memory: A Comparative Perspective on Eastern Europe', held in Warsaw, 2012, explicitly problematized the spatial framework of memory studies (conference report at http://hsozkult.geschichte.hu-berlin.de/tagungsberichte/id=4715\&view=pdf; accessed 8 Feb. 2018); U. Blacker, A. Etkind, J. Fedor (eds), Memory and Theory in Eastern Europe (Basingstoke: Palgrave Macmillan, 2013) gives a good sampling of the debates; on genocide, Timothy Snyder's Bloodlands (London: Bodley Head, 2010) prompted debate about the choice of the Soviet Union and Nazi Germany as the primary units of comparison (and Snyder's lack of attention to other perpetrators, as well as other parallel cases of genocide in the region), and the specificity of an East(Central) European space of violence, as against a post-imperial borderland zone of genocide from the Baltic through the Black Sea to the eastern Mediterranean, as argued by e.g. Aviel Roshwald, Ethnic Nationalism and the Fall of Empires: Central Europe, Russia and the Middle East, 1914-1923 (London: Routledge, 2001). 
instance, Marcel Cornis-Pope and John Neubauer, the editors of a four-volume History of the Literary Cultures of East-Central Europe, defined its setting as a 'liminal and transitional space' in between various hegemonic powers and influences, and stretching from the Baltic to the Balkans. This then set the stage for a discussion of the literary cultures of the region not through separate national literatures but in terms of internal and external influences, transfers and interconnections, grasped through the interfaces or 'nodes' at which interactions took place. ${ }^{45}$ A similarly ambitious project (also in four volumes), Entangled Histories of the Balkans, pursued the same project of transcending national(ist) histories by examining contacts, transfers and interactions within and beyond the regional framework. ${ }^{46}$ In both these cases, the transnational approach has helped reinvent the object of area studies less as bounded entities and more as shifting and asymmetrical spaces of encounter. But juxtaposing these two projects raises the question of why chose this or another wider or narrower area, East-Central Europe or the Balkans, particularly when the connections traced extend well beyond the regional framework? Doesn't the transnational mesoregional approach merely reconstruct and reinforce conventional definitions of areas? In fact, these projects, in large part because of their ambitious scope, underline the utility of multiple spatial frameworks, each appropriate to a specific period or problematic. The study of interactions and connections problematizes bounded, stand-alone approaches to nation-states or mesoregions, but it also shows that the problem cannot be solved simply by shifting up a scale, placing it 'in context'. East-Central Europe appears as a zone of divergences and disjunctures, as well as encounters and transfers, while the history of the Balkans is entangled not just on an intra-regional level, but also in ways that make sense in both European and 'Near Eastern' contexts, as well as linking (or dissolving into) still other spaces of interaction, e.g. the oceanscapes of the Mediterranean, the Adriatic, and the Black Sea. ${ }^{47}$

All in all, the sense of crisis in East European Studies beginning in the 1990s, together with wider intellectual trends, worked to produce a more critical awareness of what went into the framing and reproduction of a variety of spaces, including Eastern Europe, as an object of study and challenged static and bounded concepts of 'area'. In the meantime, however, institutional East European Studies is once again on the rise, fuelled by political developments (EU relations with its eastern neighbors, right-wing populism, the response to the

\footnotetext{
45 Marcel Cornis-Pope and John Neubauer (eds), History of the Literary Cultures of EastCentral Europe (Amsterdam: John Benjamins Press, 2004-2010).

${ }^{46}$ Roumen Daskalov and Tchavdar Marinov (eds), Entangled Histories of the Balkans (Brill: Leiden, 2013-17).

${ }^{47}$ Alexander Vezenkov, 'Entangled Geographies of the Balkans: The Boundaries of the Region and the Limits of the Discipline', Entangled Histories of the Balkans, 4 (Brill: Leiden, 2017), 115-256, makes this case particularly clearly.
} 
refugee crisis, the challenge of 'illiberal democracies', and uncertainty in relation to Putin's Russia, including the war in Ukraine), security concerns (including the need for regional and linguistic expertise), the perceived utility of area studies expertise for practical application by business and policy users, employment opportunities, and even the intellectual possibilities of interdisciplinary interaction. To an extent, East European Studies' funding is still determined by state interests: in the United States, federal funding for area research hinges on a demonstration of 'policy relevance', while in the UK, the funding mechanism covered by REF requires proof of 'impact' on non-academic audiences, though it is worth underlining that this covers all academic research, across the sciences and humanities, and not simply area studies. (Inevitably evidence of influence on policy-makers - rather than poetry-readers - is the easiest to come by.)

So at present, the question is no longer how to 'normalize' East European Studies, or whether to dissolve it into its constituent disciplinary parts. Instead, the issue is the challenges and opportunities that these circumstances bring, and the staying power of the lessons learnt in the recent period of self-reflection. Some lingering anxieties may be overblown: seeing East European Studies as subservient to 'strategic interest' overstates either academic naiveté or cynicism, and denies individuals agency and commitment. Academics, like others, grapple as best they can with real-world problems, and must take responsibility for their ethical and political choices. More problematic is something else that is inherent to Area Studies: the temptation to focus more on the differences that distinguish a region - let's say Eastern Europe - than on variation within the region, or even more, the common traits that it shares across regional borders. There is almost a professional reflex to put the emphasis on specificity and uniqueness, on 'East Europeanness'. This is not just because to do otherwise undermines the coherence of an area and thus the justification for its study. It also allows the area specialist to claim the privileged position of interpreter of a specific East European 'otherness' - and in the process, reproduces that 'otherness', those ideologies of Eastness. Subject/object relations in East European Studies remain an ethical problem. At the same time, however, the entangled character of East European Studies discussed above - constituted neither as solely externally nor internally generated knowledge - usefully problematizes the location of subject and object: the boundaries between them, like the boundaries of Eastern Europe, are not easy to specify.

This brings us back to the possibility of an Area Studies project inspired by Dziachkowski's collages: East European Studies with and without borders. What might it involve? East European Studies, as emphasized above, has employed a wide variety of units of analysis, scaling up and down: from neighbourhoods to cities to states to regions to the area, by whatever name. That said, all such 
spatial frameworks, while empirically ascertainable, in scholarly terms serve as contingent and provisional heuristic devices: both generating questions, and acting as a framework for exploring them. The point is not 'do they exist as such?' but 'what are they useful for?' Not as a political programme, or a fundraising mechanism, or even as a means of defending vulnerable subjects, but as the framework within which research questions can be asked and explored. Most questions, as suggested by the hierarchically ordered scale above, have taken 'container' concepts of territory for granted: this is the way that the world is politically divided and ruled. But it follows that in circumstances in which culture, knowledge, and power are not contained within neatly bounded territorial units, it makes sense to look for alternative ways of conceptualizing space and different questions. Literary interactions, transfers of ideas, trading relationships, or the movement of people and commodities prompt us to trace routes, flows, commodity chains, or networks and to ask about obstacles in the path, friction, or the nodes where people and processes converge. The existence of far-flung diasporic communities might cause us to recognize terrestrial archipelagos, and ask what links these separate islands and how they interact or not with the currents that surround them. Above all, we might ask about what borders do: when are they boundaries and when are they interfaces, defining rather than dividing areas? These are not new questions in East European Studies, but they suggest ways in which not just the content but the contours of the field might be reconceptualized.

How might the notion of 'with and without borders' be translated into the relations between academic cultures and communities, and help rethink the production of knowledge more generally? First, thinking of borders as interfaces as well as boundaries helps to reframe questions about the vexed relations between discipline and area. The disciplines and area studies operate according to different epistemologies, and they organize the production of knowledge differently. The assumptions and claims of the disciplines are rooted in an understanding of reality as structured according to the separate, independent domains of society, culture, politics, and economics, changing over time. The nineteenth century conventionally framed and institutionalized each of these disciplinary domains within (and at the service of) the nation-state and according to global hierarchies of power and prestige. This framework, though often challenged, has remained hegemonic. Area studies, in contrast, takes concepts of space as the starting point for enquiry, and pursues problems that arise from the interaction of the disciplinary domains on the ground and in context. It is no accident that some interdisciplinary configurations have arisen from studying the complexity of area-based realities: for instance, the modern concept of 'political economy' as the 'continual and reciprocal relationship between the political and the economic' arose from the study of a particular time 
and place (interwar Romania in its regional context). ${ }^{48}$ Nor is it surprising that area-based knowledge has served as an important check on the validity and extent of disciplinary claims. ${ }^{49}$ However, area studies has tended to translate its organization of knowledge into disciplinary or cross-disciplinary terms rather than engage in independent theory building. This is now changing, driven by two impulses: attempts to chart the complexity of area studies' spatial frames, and attention to the entangled histories of area studies themselves. An awareness of the boundaries between area and discipline does not lead to one dissolving into the other; instead, it maintains a productive tension between their different perspectives.

A different set of borders and interfaces between academic communities involves the relations between here, there and elsewhere. What distinguishes or connects East European Studies as seen from the universities of Chicago, London, Berlin, Warsaw, Beijing, and Hokkaido, all of which have area studies centres under that label? This raises a cluster of questions around the political dimensions of knowledge production, encompassing not only positionality - who studies whom and where - but also asymmetries in the legitimation, circulation, and assimilation of knowledge. This is a more complex problem than that of the 'local' scholar and 'Western' expert. As noted above, the entangled genealogy of East European Studies renders this problematic; so too do the nesting ideologies of Eastness - and these complexities are mirrored, if not precisely reproduced, across other academic communities spanning global divides. Recognizing the politics of area knowledge thus requires recognizing multiple borders, competing hegemonies, and a multidimensional distribution of power and legitimating authority. These crisscross borders and intersecting interfaces make a simple reversal of perspective problematic: claiming centrality for one's own location in the production of knowledge simply produces new hierarchies. But border crossing under such circumstances facilitates useful shifts in perspective. The prize is not just an awareness that there is more than one possible way of seeing the world (worthwhile in itself), but also the possibility of rethinking the politics of knowledge production. One such model might draw on Galin Tihanov's

${ }^{48}$ Henry Roberts, Rumania: Political Problems of an Agrarian State (New Haven, CT: Yale UP, 1951), vii; cited (and the point about political economy made) in Joseph Rothschild, 'Henry L. Roberts and the Study of the History and Politics of East Central Europe', in Historians as Nation-Builders: Central and South-East Europe, ed. Dennis Deletant and Harry Hanak (Macmillan/SSEES, 1988), 206-15.

${ }^{49}$ For an excellent example, see Zoran Milutinovićs critique of Pascale Casanova's interpretation of international literary space as constituted by the 'great consecrating nations' of the West. By showing that writing from a geopolitical periphery (Kiš's Belgrade) does not equate to writing from the periphery of world literary space and time, he reveals the way that Casanova (inadvertently?) re-maps the literary world according to the criteria of economic and political power: Zoran Milutinović, 'Territorial Trap: Danilo Kiš, Cultural Geography, and Geopolitical Imagination', East European Politics and Societies 28/4 (2014): 715-38. 
radical shift in perspective in examining the origins of modern literary theory in central and eastern Europe. He doesn't just challenge the notion of East/West 'lag', but displaces mono-directional models of influence or genealogy, proposing instead the concept of historically specific 'regimes of relevance' - based on the prevalent modes of literary consumption in a society at a particular time, whether for its social or political critique, its aesthetic qualities, as therapy, entertainment, or a window into the world. ${ }^{50}$ Such 'regimes of relevance' might offer a useful model for understanding how area studies work within and across academic cultures, depending on their mode of knowledge production: whether as an exercise of power, in the service of resistance and emancipation, driven by market-based utilitarianism, or as a search for alternatives. Cross-border collaboration, under such conditions, goes beyond essentialized positions of subject/object, foreign/indigenous, and allows us to think of academic agency in area studies more critically.

And finally, the slogan of 'with and without borders' should encourage us to look more critically at other borders between academic communities. Despite widespread recognition that the world is not neatly subdivided into separate and autonomous areas, our academic institutions often act as though this is the case as far as Area Studies research initiatives, institutional structures and teaching programmes are concerned, with little cross-border communication or cooperation. This volume is in itself a welcome exception. Elsewhere, efforts are being made to systematize comparative Area Studies, taking methodological tools from comparative politics to develop a framework for comparing political phenomena within and across areas; ${ }^{51}$ while transnational and transregional approaches have also fed into 'cross-area' studies, bringing the perspectives and structures of different area studies frameworks into useful contact. ${ }^{52}$ But a critical Area Studies is also well placed to examine and problematize the

\footnotetext{
50 Tihanov, op. cit.

51 Matthias Basedau and Patrick Köllner, 'Area Studies, Comparative Area Studies, and the Study of Politics: Context, Substance, and Methodological Challenges', Zeitschrift für Vergleichende Politikwissenschaft 1/1 (2007): 105-124; and see now also Ariel I. Ahram, Patrick Köllner and Rudra Sil (eds.), Comparative Area Studies: Methodological Rationales and Cross-Regional Applications (New York: Oxford University Press, 2018).

52 The ESRC-funded project 'Socialism Goes Global', examining Second world/Third World exchanges in different fields, including academic collaborations, is a good example of cross-area studies as history and as practice (http://socialismgoesglobal.exeter.ac.uk/). A comprehensive programme of rethinking Area Studies in a cross-area and transregional framework in Katja Mielke and AnnaKatharina Hornidge (eds), Area studies at the crossroads: knowledge production after the mobility turn (Basingstoke: Palgrave Macmillan, 2016).
} 
institutional and intellectual borderlines between other fields: Global Studies, Migration Studies, Urban Studies, Borderland Studies, Oceanic Studies, and so on. Each of these is constituted around a particular conceptualization of space and set of problems, but here too the communication between such fields is limited. Without dismantling the borders between such endeavours, a critical and reflexive Area Studies offers an opportunity to consider the understandings of space and process that underpin such approaches, and at the same time refine the notion of 'area' as a useful and flexible concept.

The critique of Area Studies in general, and East European Studies in particular, has led to calls for 'post-Area Studies' or Area Studies 'without borders' - the title of the conference that generated this volume. Rethinking the borders that delimit our intellectual endeavours is necessary and valuable, particularly to the extent that it allows us to see what limits convention places on our efforts, and to transcend them. But at the same time, Dziaczkowski's ironic images of a Europe 'without borders' serve as a reminder that the move to erase borders is not always emancipatory. Dziaczkowski's collages hint at the sedimentary and symbolic dimensions of East European borders; ignoring them is to devalue the experiences and perceptions of those whose lives and identities have been shaped by such borders. An Area Studies 'with and without borders' is needed to do justice to the complex reality of lived experience and its scholarly study. 